\title{
To Determine the Morphological Changes in Red Blood Cells During Storage in Blood Banks
}

\author{
SM Tahir ${ }^{1}$, Wajid Akbar ${ }^{2}$, Asadullah $^{3}$, Usmanullah ${ }^{1}$, Usman Ali², Humaira Imtiaze ${ }^{4}$
}

\begin{abstract}
Background: During storage of blood, the red blood cells undergo shape changes which cause fragility and endothelial interaction leading to deterioration the quality of blood in blood banks.

Objectives: The aim of this study is to determine the morphological changes in red blood cells during storage in blood banks.

Material and Methods: In this experimental study, a total 20 healthy volunteers between 17 to 40 years blood donors-Blood bags were taken, ten from each center i.e. MMCTH blood bank Mardan and KTH blood bank Peshawar. The specimen analysis was done at IBMS (Institute of Basic Medical Sciences) of KMU (Khyber Medical University) Peshawar. The exclusion criteria were People with anemia, hepatitis B \&C, HIV and syphilis. The duration of this study was six months. The inform consent was taken from each donor. The total blood $250 \mathrm{ml}$ from vein in cubital fossa from each blood donor was collected in $250 \mathrm{ml}$ pediatric blood bag with CPDA-1 solution. Blood bags were put up in the blood bank at +2 to $+6{ }^{\circ} \mathrm{C}$ and stored till 20 days. Blood specimen of about $5 \mathrm{cc}$ were collected in $5 \mathrm{cc}$ syringe from each blood bag on $0,5^{\text {th }}, 10^{\text {th }}, 15^{\text {th }}$ and $20^{\text {th }}$ day for following parameters and thin film red blood cell was prepared for examination by light microscope. Morphological changes in RBCs examined via light microscope as well as grading the RBCs status in the peripheral blood film, the occurrence of distorted RBC simply in random fields; such as +1(scored 1 to 5 altered RBC present in each field), +2 (an average of 6 to 15 altered RBC in each field), $+3(16$ to 25 altered RBC in each field) and +4 (more than 25 altered RBC present in each field). The multi head light microscope NIKON eclipse 50 was used for examination of peripheral blood slide and we took images of randomly selected field. The image $\mathrm{J}$ software was used for slide examination.

Results: The morphological analysis of red blood cells, count of 200 cells in each blood slide in randomly selected fields are: On day 0 the majority of cells were normally shaped $(97.95 \pm 1.297$ (mean $\pm S D)$. With increasing storage time, the percentage of morphologically abnormal red cells rose sharply. Mean percentage of abnormal cells on day $5,10,15$ and 20 was $28.80 \pm 10.00$, $51.73 \pm 12.47,64.78 \pm 14.66$ and $68.10 \pm 7.92$ respectively. This increase in percentage of abnormally shaped cells was significant as determined by one way ANOVA $(p=0.001)$. There was a big difference of percentage of abnormal RBCs on day 0 and in $=5$ to $=$ 10 days and in $=15$ to $=20$ days of blood storage. The mean values of day 0 of abnormal cells was $2.05 \pm 1.297$ (Mean \pm Std . Deviation), abnormal cells in $=5 \mathrm{to}=10$ days was $40.26 \pm 16.101$ (Mean \pm Std. Deviation) and on day $=15$ and in $=20$ day was $66.44 \pm 11.75$. The mean difference from day 0 to day 20 was $63.93 \pm 10.45$ (Mean \pm Std. Deviation). The one way ANOVA was significant, $P=0.001$.

Conclusion: This study confirms the hematological and morphological changes, when blood stored at $2{ }^{\circ} \mathrm{C}$ to $6{ }^{\circ} \mathrm{C}$ for up to 21 days. The significant morphological changes were observed on $5^{\text {th }}$ day of blood storage. These findings suggested that approximately a week old stored blood is as good as the fresh blood; however, significant morphological and biochemical changes begin to appear after the first week of storage and these changes aggravate with time. Hence in order to achieve best possible transfusion outcomes, stored blood up to one week can be utilized.
\end{abstract}

Key words: Red blood cells, Blood bank, Morphological changes

This article may be cited as: Tahir SM, Akbar W, Asadullah, Usmanullah, Ali U, Imtiaze H

To determine the morphological changes in Red Blood Cells during storage in blood banks. J Saidu Med Coll Swat 2020;10(2):96-102

\section{INTRODUCTION}

In Pakistan the blood banks follow the international guidelines to store the blood for a maximum of 42 days. However the condition in which the blood is stored is not standardized. Hence this stored blood is prone to developed early structural and biochemical changes. As a result of this, the quality of blood deteriorates with time. Blood is composed of plasma and cells like erythrocytes (red blood cells), platelets and leukocytes (white blood cells) ${ }^{1}$. Human

1. Department of Anatomy Gajju Khan Medical College, Swabi.

2. Department of Anatomy, Bacha Khan Medical College, Mardan.

3. Department of Anatomy, Saidu Medical College, Swat.

4. Department of Anatomy, Ayub Medical College, Abbot Abad.

Correspondence: Dr. Wajid Akbar

Assistant Professor, Department of Anatomy,

Bacha Khan Medical College, Mardan.

Email: drwajidakbar@yahoo.com Cell \#03009176437

Received: September 24th, 2019, Accepted: August 15th, 2020 erythrocyte is a flexible non nucleated biconcave disk $^{2,3}$. During storage the blood passes through different morphological, structural and metabolic changes, which cause in decreased deformability and increased red cell endothelial interaction and fragility $^{4}$. These changes are called storage lesions ${ }^{5}$. These changes give red blood cells echinocyte, stomatocyte and spherocytic morphological appearances as compared to the normal discoid shape ${ }^{6}$. From a morphological point of view, light microscope quite reliably examines the peripheral blood smear ${ }^{7}$.

The objective of this study is to determine the morphological and haematological changes in red blood cells during storage in blood banks of Mardan Medical Complex Teaching Hospital Mardan and Khyber Teaching Hospital MTI hospital Peshawar. The results of this study will 
not only indicate appropriateness of storage conditions in the local blood bank but will also help us develop guidelines for blood storage and transfusion in the local settings. More importantly, this will be a first of its kind to investigate the ultrastructure changes in stored blood in Khyber Pakhtun khawa province of Pakistan. The results will be used to further investigate intra-cellular mechanisms of increased red cell fragility with hemoglobin level.

\section{MATERIALAND METHODS}

The study was carried out in the Blood banks of Pathology departments of Mardan Medical Complex Mardan and Khyber Teaching Hospital Peshawar and University Peshawar and Institute of Basic Medical Sciences of Khyber Medical University Peshawar, Pakistan. The ethical approval was taken from Advanced Study and Research Board under: DIR/KMUAS\&RB/TD/000547, and Ethical Board under: DIR/KMU-EB/TD/000335. This was an experimental study. Firstly, to examine and assess the quality of stored blood in the blood banks, the samples were collected from two different blood banks. The specimen analysis was done at Institute of Basic Medical Sciences of Khyber Medical University Peshawar.

In this study, a total 20 healthy blood donors. Blood bags were taken, ten from each center i.e. MMCTH blood bank Mardan and KTH blood bank Peshawar. The average ages of blood donors was kept between 17 to 40 years, based on Erik Erikson classification (Erikson's stages of psychosocial development) of young adult ${ }^{8}$. Healthy volunteer blood donors, comprising of both young adult males and females were included in the study. People with anemia, hepatitis B,C, HIV, syphilis and those who were not suitable according to WHO criteria were excluded from study. The duration of this study was six months. Informed consent was taking from all donors and screening were done for VDRL, HIV, Hepatitis B,C and malaria.

The donor was advised to lie in a supine position and specimen of venous blood was collected from the vein in cubital fossa after cleaning it with spirit swab. The total blood $250 \mathrm{ml}$ from each blood donor was collected in $250 \mathrm{ml}$ pediatric blood bag with CPDA-1 solution. Blood bags were put up in the blood bank at +2 to $+6{ }^{\circ} \mathrm{C}$. The initial blood sample was collected for base line parameters on first day within four hours of donor blood collection. Before sampling the whole blood bags were mixed by mechanical tray to prevent blood clotting, as the subsequent blood samples were collected at the interval of 5 days on $5^{\text {th }}$, 10th, $15^{\text {th }}$ and $20^{\text {th }}$ day of blood storage. Internationally the blood can be stored up to 42 days. We stored blood till to 20 days because we observed in my piloting study that the morphological changes started on $6^{\text {th }}$ day of blood storage. Blood specimen of about $5 \mathrm{cc}$ were collected in $5 \mathrm{cc}$ syringe from each blood bag on $0,5^{\text {th }} 10^{\text {th }}, 15^{\text {th }}$ and $20^{\text {th }}$ day for following parameters and thin film red blood cell was prepared for examination by light microscope.

Morphological changes in RBCs examined via light microscope as well as grading the RBCs status in the peripheral blood film, the occurrence of distorted RBC simply in random fields; such as +1 (scored 1 to 5 altered RBC present in each field), +2 (an average of 6 to 15 altered RBC in each field), +3 (16 to 25 altered RBC in each field) and +4 (more than 25 altered RBC present in each field) ${ }^{9}$. For making the peripheral blood smear, slides, pipette/capillary tube and blood spreader are needed. Avery commonly used push (Wedge) method was applied to prepare the blood slides ${ }^{10}$. A drop of mixed blood was put on one end of slide about $1 \mathrm{~cm}$ from the edge with pipette. The spreader slide with chipped end was kept on the base slide in front of blood drop and was pushed backwards to touch the blood drop, which made the blood spread along the base slide width. Once the Spreader had a smooth end to make proper tail on the slide it was inclined at 30 to 45 degree to the blood slide. Care was taken to avoid excessive pressure on the spreader slide while smearing. The blood smear was duly air-dried. The dried smear was fixed with absolute ethyl alcohol and stained with a gemisa stain for about 10 to 20 minutes to allow good fixation. The smear stained for 5 to 10 minutes, then diluted twice with buffered water and kept for 5 to 10 minutes to absorb the stain .At the end the slides were wash with running water and placed on the rack to air dry ${ }^{10,11}$.

Giemsa staining is one of the romanowsky stains commonly using in hematology .It stain nuclei as red and cytoplasm as blue. Method: get ready smear and then dry it. Followed by fixation in methanol for three to five minutes and keep it to dry in air. Put in 1:10 diluted Giemsia stain for 30 to 45 minutes. One percent Sodium carbonate used 
as diluents instead of distilled water. Wash with water, blot dry and examine. The multi head light microscope NIKON eclipse 50 was used for examination of peripheral blood slide. Initially the slide examined by $10 x, 20 x$ and $40 x$ power magnification. In 40x power of magnification which is maximum power of setting to examined the morphology of RBCs, for that aim we selected randomly four fields on blood slide. We took images of randomly selected field by already installed camera in multi head microscope and display it by monitor which is attached to multi head microscope and stored the capture images to the USB. For examination of morphology of $\mathrm{RBC}$ the grid with magnification of $10 \mu \mathrm{m}$ was displayed on image to make multiple squares and started counting of RBC from up to down and from left to right, and are selected the right lower corner for counting. The image $\mathrm{J}$ software was used for slide examination. After flatting the image, we were able to mark the red blood cells in field and count total 200 red blood cells in four randomly selected fields in each slide and used the grading criteria of Cora et al. The counting of existence of distorted RBC in random fields; $1+$ mean that 1 to 5 modified red blood cells in the field, $2+$ mean that 6 to 15 altered RBC in the field , $3+$ mean that 16 to 25 changed red blood cells in the field in addition to $4+$ mean that the number of altered $\mathrm{RBC}$ in each field more than $25^{\circ}$ as indicated in table 1 and figure 1 respectively.

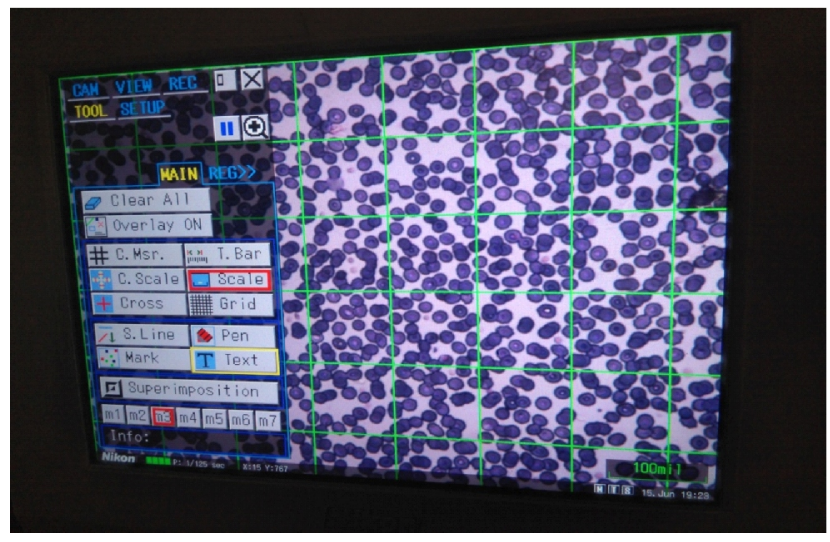

Figure 1. Grid for counting of red blood cells
Data was analyzed via SPSS software version 22. Image $J$ software was used to verify the morphological changes on the Grid of micrographs obtained by Multi Head NIKON Microscope 50i. A quantitative statistics was also evaluated by applying the t-test for single time points and analysis of variance (ANOVA) for multiple time points during the storage period. Results are declared as Mean \pm Standard Deviation (Std. Deviation), with 95\% confidence interval and a $p$-value of $<0.05$ was measured significant.

\section{RESULTS}

The morphological analysis of red blood cells, count of 200 cells in each blood slide in randomly selected fields is: On day 0 the majority of cells were normally shaped (97.95 \pm 1.297 (mean $\pm S D)$.With increasing storage time, the percentage of morphologically abnormal red cells rose sharply. Mean percentage of abnormal cells on day $5,10,15$ and 20 was $28.80 \pm 10.00$, $51.73 \pm 12.47,64.78 \pm 14.66$ and $68.10 \pm 7.92$ respectively. This increase in percentage of abnormally shaped cells was significant as determined by one way ANOVA ( $p=0.001)$. Figure 2.

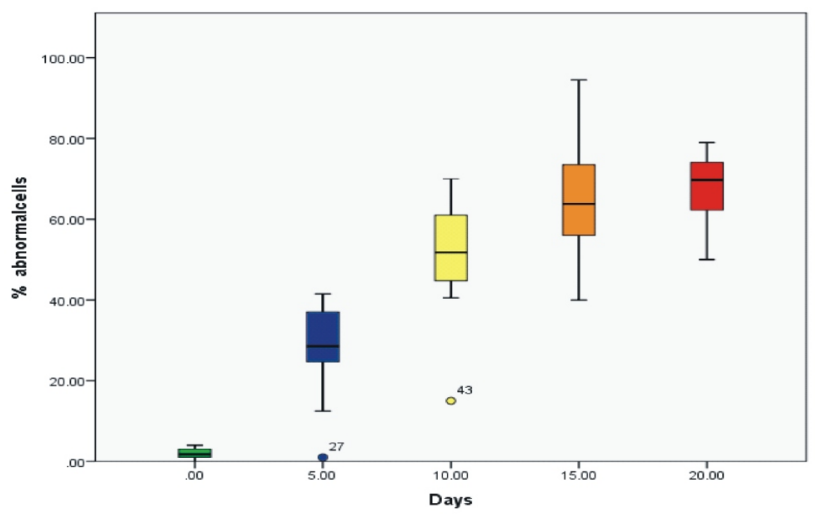

Figure 2. Box plot showing the percentage of abnormal RBCs in response to days $0,5,10,15$ and 20 . Horizontal stripe in the box shows median, whiskers above and below serve as $10^{\text {th }}$ and $90^{\text {th }}$ percentile. Points above and below whiskers represent outliers.

Table 1. Grading criteria of Cora et al. for counting of $\mathbf{R B C s}^{9}$

\begin{tabular}{|c|c|}
\hline Number of altered RBCs in the field & Score \\
\hline $1-5$ & +1 \\
\hline $6-15$ & +2 \\
\hline $16-25$ & +3 \\
\hline More than 25 & +4 \\
\hline
\end{tabular}


There was a big difference of percentage of abnormal RBCs on day 0 and in $=5$ to $=10$ days and in $=15$ to $=20$ days of blood storage. The mean values of day 0 of abnormal cells were $2.05 \pm 1.297$ (mean \pm Std. Deviation), abnormal cells in $=5$ to $=10$ days was $40.26 \pm 16.101$ (Mean \pm Std. Deviation) and on day $=15$ and in $=20$ day was $66.44 \pm 11.75$. The mean difference from day 0 to day 20 was $63.93 \pm 10.45$ (Mean \pm Std. Deviation). The one way ANOVA was significant, $P=0.001$ (figure 3 ).

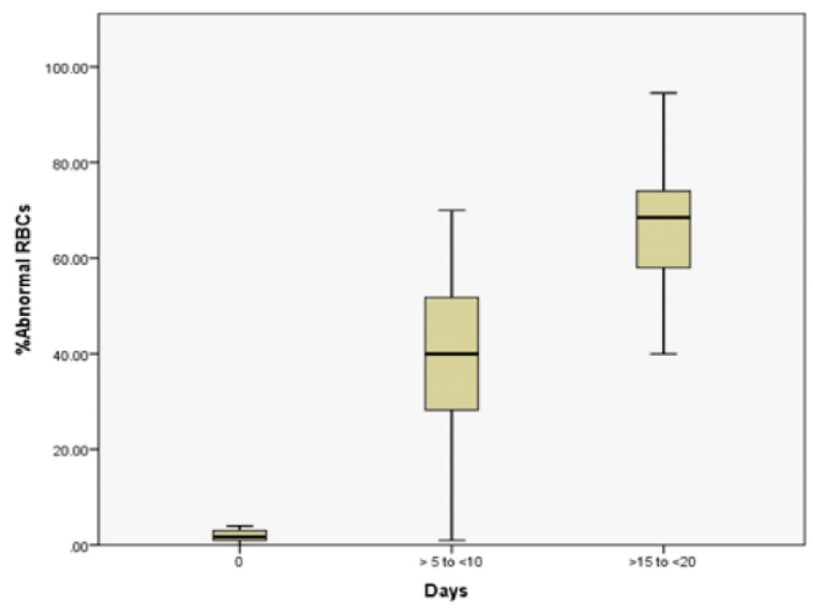

Figure 3. Box plot showing percentage of abnormal $\mathrm{RBCs}$ at days $0,=5$ to $=10$ days and $=$ 15 to $=20$ days. Horizontal column in the box express median, whiskers above and below show $10^{\text {th }}$ and $90^{\text {th }}$ percentile.

The Semi Quantitative analysis of red blood cells used Cora et al. criteria are: the existence of distorted RBC in casual fields; +1 mean that 1 to 5 deformed RBC present in every field, +2 an average of 6 to 15 changed RBC in every field, +3mean 16 to 25 altered RBCmoreover+4 mean more than 25 altered RBC present in every field as shown in table 2 and figure 4, 5, 6, 7 and 8 respectively.

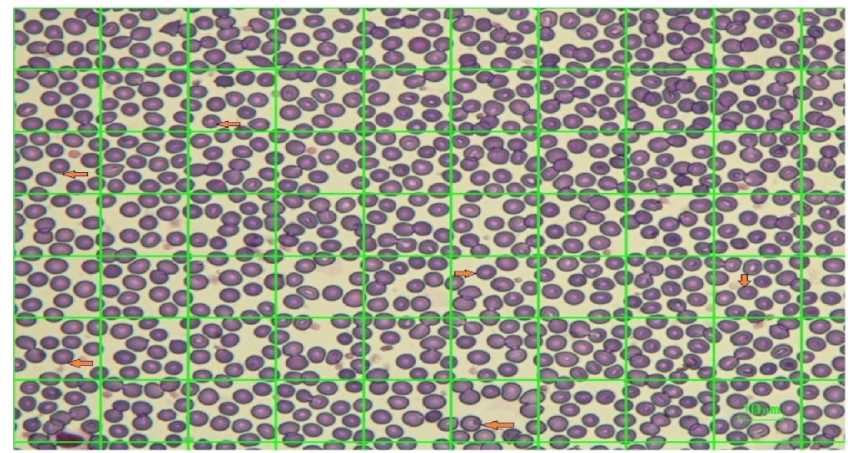

Figure 4. Shows normal morphology of red blood cells on day 0 (Giemsa stain $400 \mathrm{x}$ ) Cells were visualized on a compound microscope, images taken using Nikon Eclipse 50i software, analyzed on Image J. Arrows represent selected normal cells. Scale bar $=10 \mu \mathrm{m}$

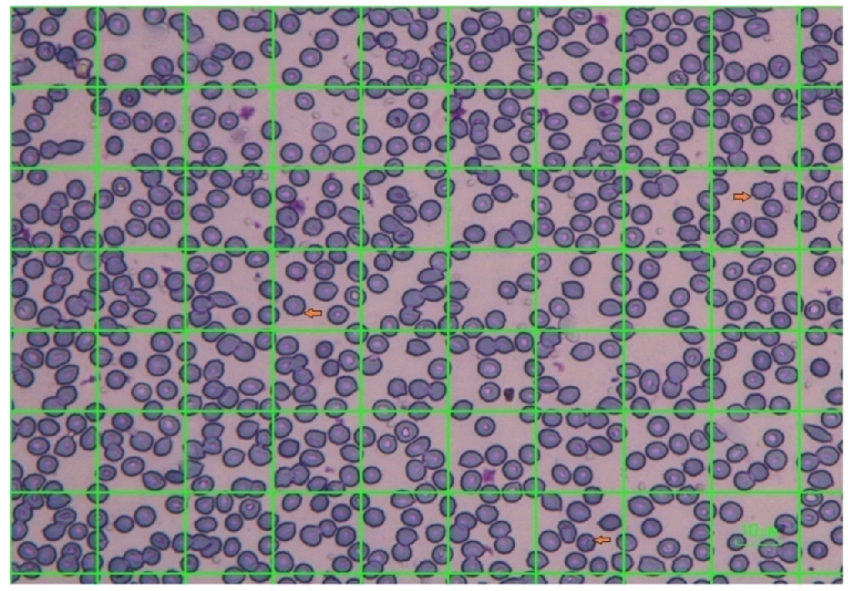

Figure 5. with arrows shows morphological changes in red blood cells on day 5 (Giemsa stain $400 \mathrm{x}$ ) Cells were visualized on a compound microscope, images taken using Nikon Eclipse 50i software, analyzed on Image J. Arrows represent selected abnormal cells. Scale bar $=10 \mu \mathrm{m}$

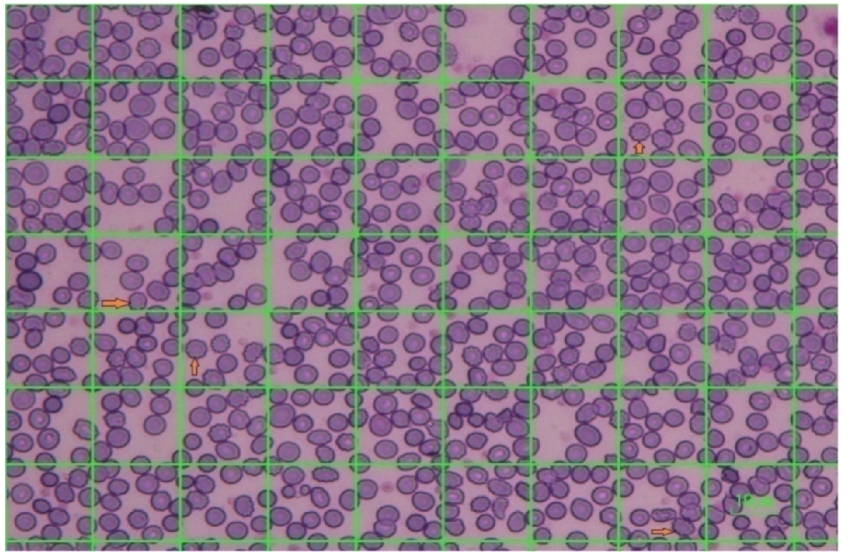

Figure 6. With arrows shows morphological changes in RBC on day 10 (Giemsa stain $400 \mathrm{x}$ ) Cells were visualized on a compound microscope, images taken using Nikon Eclipse 50i software, analyzed on Image J. Arrows represent selected abnormal cells. Scale $=10 \mu \mathrm{m}$ 


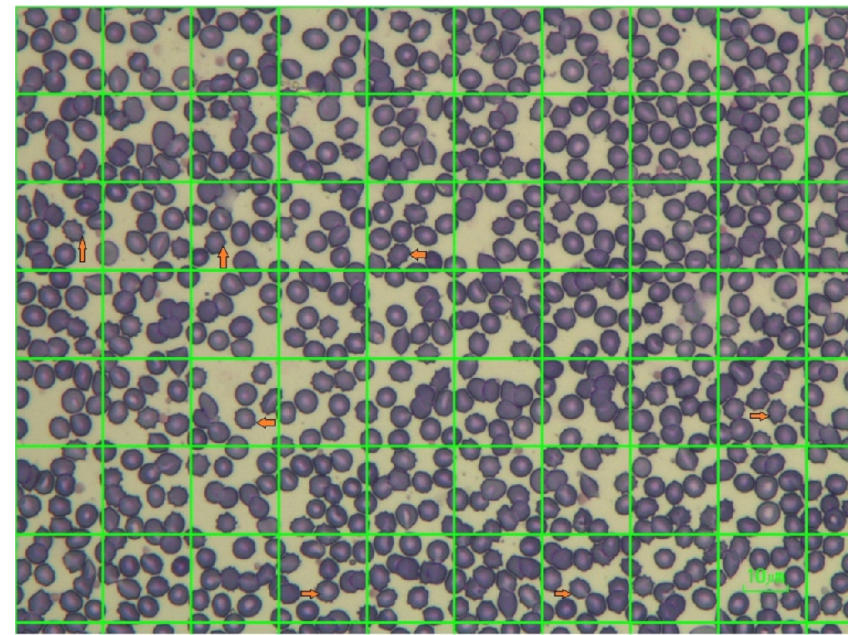

Figure 7. Shows morphological changes in RBC on day 15 (Giemsa stain $400 \mathrm{x}$ ) Cells were visualized on a compound microscope, images taken using Nikon Eclipse 50i software, analyzed on Image J. Arrows represent selected abnormal cells. Scale bar $=10$

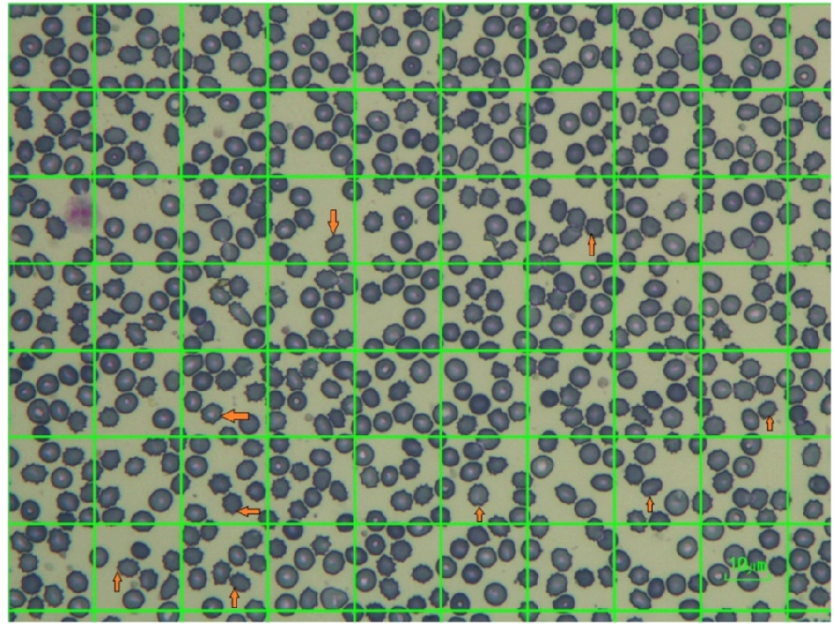

Figure 8. Shows abnormal morphology of RBC on day 20 (Giemsa stain $400 \mathrm{x}$ ) Cells were visualized on a compound microscope, images taken using Nikon Eclipse 50i software, analyzed on Image J. Arrows represent selected abnormal cells. Scale $=10 \mu \mathrm{m}$

Table 2. Shows the percentage of normal and abnormal cells with Cora et al. scoring

\begin{tabular}{|c|c|c|c|c|c|c|c|}
\hline Samples & Days & $\begin{array}{c}\text { No. of } \\
\text { abnormal } \\
\text { cells }\end{array}$ & $\begin{array}{c}\text { Cora et } \\
\text { al. } \\
\text { scoring }\end{array}$ & samples & Days & $\begin{array}{c}\text { No of } \\
\text { abnormal } \\
\text { cells }\end{array}$ & $\begin{array}{c}\text { Cora et al. } \\
\text { scoring }\end{array}$ \\
\hline \multirow{4}{*}{1} & 0 & 3 & $1+$ & & 0 & 5 & $1+$ \\
& 5 & 52 & $4+$ & & 5 & 77 & $4+$ \\
& 10 & 140 & $4+$ & 6 & 10 & 137 & $4+$ \\
& 15 & 176 & $4+$ & & 15 & 189 & $4+$ \\
& 20 & 148 & $4+$ & & 20 & 140 & $4+$ \\
\hline \multirow{4}{*}{2} & 0 & 5 & $1+$ & & 0 & 2 & $1+$ \\
& 5 & 25 & $4+$ & & 5 & 60 & $4+$ \\
& 10 & 132 & $4+$ & 7 & 10 & 123 & $4+$ \\
& 15 & 127 & $4+$ & & 15 & 137 & $4+$ \\
& 20 & 139 & $4+$ & & 20 & 120 & $4+$ \\
\hline \multirow{4}{*}{3} & 0 & 8 & $2+$ & & 0 & 1 & $1+$ \\
& 5 & 49 & $4+$ & & 5 & 41 & $4+$ \\
& 10 & 30 & $4+$ & 8 & 10 & 107 & $4+$ \\
& 15 & 87 & $4+$ & & 15 & 132 & $4+$ \\
& 20 & 158 & $4+$ & & 20 & 148 & $4+$ \\
\hline \multirow{6}{*}{4} & 0 & 0 & $0+$ & & 0 & 1 & $1+$ \\
& 5 & 70 & $4+$ & & 5 & 75 & $4+$ \\
& 10 & 89 & $4+$ & 9 & 10 & 93 & $4+$ \\
& 15 & 80 & $4+$ & & 15 & 156 & $4+$ \\
& 20 & 142 & $4+$ & & 20 & 124 & $4+$ \\
\hline
\end{tabular}




\begin{tabular}{|c|c|c|c|c|c|c|c|}
\hline 5 & $\begin{array}{c}0 \\
5 \\
10 \\
15 \\
20\end{array}$ & $\begin{array}{c}3 \\
53 \\
95 \\
97 \\
100\end{array}$ & $\begin{array}{l}1+ \\
4+ \\
4+ \\
4+ \\
4+\end{array}$ & 10 & $\begin{array}{c}0 \\
5 \\
10 \\
15 \\
20\end{array}$ & $\begin{array}{c}6 \\
56 \\
114 \\
137 \\
125\end{array}$ & $\begin{array}{l}2+ \\
4+ \\
4+ \\
4+ \\
4+\end{array}$ \\
\hline samples & Day & $\begin{array}{c}\text { No of } \\
\text { abnormal } \\
\text { cells }\end{array}$ & $\begin{array}{c}\text { Cora et } \\
\text { al. } \\
\text { scoring }\end{array}$ & Samples & Days & $\begin{array}{c}\text { No. of } \\
\text { abnormal } \\
\text { cells }\end{array}$ & $\begin{array}{c}\text { Cora et } \\
\text { al.scoring }\end{array}$ \\
\hline 11 & $\begin{array}{c}0 \\
5 \\
10 \\
15 \\
20\end{array}$ & $\begin{array}{c}2 \\
73 \\
122 \\
122 \\
136\end{array}$ & $\begin{array}{l}1+ \\
4+ \\
4+ \\
4+ \\
4+\end{array}$ & 16 & $\begin{array}{c}0 \\
5 \\
10 \\
15 \\
20\end{array}$ & $\begin{array}{c}5 \\
75 \\
84 \\
128 \\
154\end{array}$ & $\begin{array}{l}1+ \\
4+ \\
4+ \\
4+ \\
4+\end{array}$ \\
\hline 12 & $\begin{array}{c}0 \\
5 \\
10 \\
15 \\
20\end{array}$ & $\begin{array}{c}2 \\
68 \\
88 \\
114 \\
118 \\
\end{array}$ & $\begin{array}{l}1+ \\
4+ \\
4+ \\
4+ \\
4+\end{array}$ & 17 & $\begin{array}{c}0 \\
5 \\
10 \\
15 \\
20\end{array}$ & $\begin{array}{c}8 \\
50 \\
90 \\
141 \\
153\end{array}$ & $\begin{array}{l}2+ \\
4+ \\
4+ \\
4+ \\
4+\end{array}$ \\
\hline 13 & $\begin{array}{c}0 \\
5 \\
10 \\
15 \\
20 \\
\end{array}$ & $\begin{array}{c}3 \\
41 \\
81 \\
112 \\
138 \\
\end{array}$ & $\begin{array}{l}1+ \\
4+ \\
4+ \\
4+ \\
4+\end{array}$ & 18 & $\begin{array}{c}0 \\
5 \\
10 \\
15 \\
20 \\
\end{array}$ & $\begin{array}{c}8 \\
69 \\
97 \\
139 \\
149 \\
\end{array}$ & $\begin{array}{l}2+ \\
4+ \\
4+ \\
4+ \\
4+\end{array}$ \\
\hline 14 & $\begin{array}{c}0 \\
5 \\
10 \\
15 \\
20 \\
\end{array}$ & $\begin{array}{c}6 \\
83 \\
118 \\
112 \\
140 \\
\end{array}$ & $\begin{array}{l}2+ \\
4+ \\
4+ \\
4+ \\
4+\end{array}$ & 19 & $\begin{array}{c}0 \\
5 \\
10 \\
15 \\
20\end{array}$ & $\begin{array}{c}4 \\
57 \\
122 \\
103 \\
107 \\
\end{array}$ & $\begin{array}{l}1+ \\
4+ \\
4+ \\
4+ \\
4+\end{array}$ \\
\hline 15 & $\begin{array}{c}0 \\
5 \\
10 \\
15 \\
13\end{array}$ & $\begin{array}{c}8 \\
57 \\
102 \\
113 \\
148 \\
\end{array}$ & $\begin{array}{l}2+ \\
4+ \\
4+ \\
4+ \\
4+\end{array}$ & 20 & $\begin{array}{c}0 \\
5 \\
10 \\
15 \\
20\end{array}$ & $\begin{array}{c}2 \\
79 \\
105 \\
153 \\
137\end{array}$ & $\begin{array}{l}1+ \\
4+ \\
4+ \\
4+ \\
4+\end{array}$ \\
\hline
\end{tabular}

\section{DISCUSSION}

In this study we observed significant difference in RBCs morphology. The morphological alterations in RBCs initiated after 5 days of storage. The reasonable justification for this observation is that the shape changes due to cytoskeleton instability in the cell membrane of red blood cells during storage. These results are consistent with pervious literature. Mustafalet al.,. showed the morphological variations in leukodepleted packed RBCs stored for 42 days in Saline, Adenine, Glucose, Mannitol (SAGM) medium 6 . They observed the morphological changes in RBCs with 14 days interval on day $0,14^{\text {th }}$ day, $28^{\text {th }}$ day and $42^{\text {nd }}$ day. Day zero was the control that showed normal morphology of RBC with typical biconcave disc shape. While the storage time prolonged the morphological changes increased significantly and observed on day 14 . These changes could have been observed earlier than 14 day, as we observed on day 5 through light microscope; however a prolonged interval of 14 days resulted in the delayed changes. Also, since we used whole blood instead of leukodepleted, this may also explain the differences observed between the two studies. Park, H.et al. ${ }^{12}$. 
measured the biophysical properties of stored RBCs by using 3-D refractive tomograms (3-D RI), calculated with common-path diffraction optical tomography(cDOT). The blood was stored with CPDA-1 and without CPDA- 1 solution and examined on day $0,5,13,20,27,34$ and 41 . In the nonexistence of CPDA-1, more than $60 \%$ of RBCs showed non-discocyte form at day 5 . In the availability of solution of CPDA-1 the morphological changes; such as non discocyte shape of RBCs were significantly less at day 5 that is only $20 \%$. Moreover, Blasi, B.,D'alessandro et al. ${ }^{13}$. stored RBCs in SAGM solution and analyzed it each week from zero day to 42 day of storage. They examined the reversible and irreversible membrane shape changes in stored blood through SEM. On day 7, irreversible changes were observed in $24 \%$ of the RBCs. These findings suggest that the morphological changes in RBCs initiate as earlier as on day 7 of storage. In other study, Kozlova, E.et al. ${ }^{14}$. Packed RBCs stored for 40 days and observed the changes through AFM. On the $5^{\text {th }}$ day of AFM images showed the morphological changes in stored blood. Collectively these finding suggest that red blood cells undergo relatively very early morphological changes in stored blood.

\section{CONCLUSION}

This study confirms the hematological and morphological changes, when blood stored at $2{ }^{\circ} \mathrm{C}$ to $6{ }^{\circ} \mathrm{C}$ for up to 21 days. The significant morphological changes were observed on $5^{\text {th }}$ day of blood storage using light. These findings suggested that approximately a week old stored blood is as good as the fresh blood; however, significant morphological and biochemical changes begin to appear after the first week of storage and these changes aggravate with time. Hence in order to achieve best possible transfusion outcomes, stored blood up to one week can be utilized limitation.

\section{LIMITATION}

The main study design limitation was to include more centers in this project to improve results. Regarding impact limitation, there should be large sample size to evaluate the storage lesion in blood banks.

\section{RECOMMENDATIONS}

Further research needs to study the storage lesion in respect of cytoskeleton changes in cell membrane of red blood cells in stored blood using immunofluorescence methods.Further studies on the effect of transfusion of stored blood in healthy and diseased patients should be carried out to comprehend the clinical implications. A detailed evaluation of blood storage condition of all the blood banks in Khyber Pakhtun khwa as well in the country will assist in modifying our storage guidelines

\section{REFERENCES}

1. Mescher AL. Junqueira's basic histology: text and atlas. (Mcgraw-hill, 2013).

2. Diez-Silva M, Dao M, Han J, Lim CT, Suresh S. Shape and biomechanical characteristics of human red blood cells in health and disease. MRS bulletin 2010; 35: 382388.

3. Pretorius E. The adaptability of red blood cells 12,63 (2013).

4. Bhaduri B, Kandel M, Brugnara C, Tangella K, Popescu G. Optical assay of erythrocyte function in banked blood. Scientific reports 4, 6211 .

5. Schapkaitz E, Pillay D. Prolonged storage-induced changes in haematology parameters referred for testing. African Journal of Laboratory Medicine 2015; 4:1-8.

6. Mustafa I, Al-Marwani A, Mamdouh Nasr K, Abdulla Kano N, Hadwan T. Time dependent assessment of morphological changes: leukodepleted packed red blood cells stored in SAGM. BioMed research international 2016.

7. Palmer L. ICSH recommendations for the standardization of nomenclature and grading of peripheral blood cell morphological features. International journal of laboratory hematology $2015 ; 37$ : 287-303.

8. Erikson EH. Identity and the life cycle: Selected papers. (1959).

9. Antwi-Baffour S, Quao E, Kyeremeh R, Mahmood S A. Prolong storage of blood in EDTA has an effect on the morphology and osmotic fragility of erythrocytes International Journal of Biomedical Science and Engineering 2013; 1:20-23

10. Adewoyin A, Peripheral blood film-a review. Annals of Ibadan postgraduate medicine 2014; 12: 71-79.

11. Houwen B. Blood film preparation and staining procedures. Clinics in laboratory medicine $2002 ; 22: 1$ 14.

12. Park $H$. Alterations in cell surface area and deformability of individual human red blood cells in stored blood. arXiv preprint arXiv 2015; 1506: 05259.

13. Blasi B, D'alessandro A, Ramundo N, Zolla L. Red blood cell storage and cell morphology. Transfusion medicine 2012; 22: 90-96.

14. Kozlova E. Morphology, membrane nanostructure and stiffness for quality assessment of packed red blood cells. Scientific reports 2017; 7: 784-86. 